\title{
The hukou and traditional virtue: An ethnographic note on Taiwanese policing
}

By Jeffrey T. Martin (Department of Sociology, University of Hong Kong, China).

\begin{abstract}
This research note suggests that traditional ideals of virtue in Taiwan enable an order-making dynamic to operate in the backstage of state record-keeping processes. These virtues coordinate cooperation by policemen, civilians and politically empowered elites, simultaneously facilitating local order-maintenance and ensuring that police records serve the interests of the established political economic structure. I focus on the ways that this arrangement is grounded in the historical institution of the population registry, or hukou. I argue that Taiwan's hukou has effectively translated traditional virtues into policeable objects of modern administration: inscribed in the documentary practices of population registration, embedded in a naturalized division of social control labor, and institutionalized as collective habits of response to trouble.
\end{abstract}

Keywords. Asian modernity, policing, traditional virtue, hukou, Taiwan.

\section{Introduction.}

Contemporary policing institutions are a product of the historical process that constituted modern society as an object known through governing technologies like the "census, map and museum" (Anderson 1991; Scott 1999; Fraser this issue). This paper presents a case study of one of these technologies - the census or "hukou" - as it functions in Taiwan. Taiwan's modern population registry was initially developed as a police technology by the Japanese colonial regime, and has remained the core of the island's police organization ever since. Here, I use an ethnography of contemporary policing to show how the practical logic of this census-based policing system continues to embody an ideal of "particularistic virtue" associated with historically Chinese or East Asian political culture (Fei 1992, Otis and Lo 2003). This demonstrates one way in which a set of ostensibly Western modern institutions - census and police - can function as "fragmented pieces" embedded in the unfolding of a distinctively Asian history (Chen 2010). As a contribution to the larger ambition of this special-issue-project to develop an Asia-centric criminology, this article suggest how the history of modernity embodied in Taiwanese policing is driven by dynamics 
internal to its local situation.

\section{Policed Society and Brokered Administration in Taiwan.}

The skyline of the Taiwanese city where I began studying police was composed of buildings topped with an architecturally distinctive pastiche known as jiagai: extra stories, rooms, pigeon houses, and other functional appendages added surreptitiously after the official paperwork had been processed. Living in such illegal housing, as I did for several years, requires borrowing a legal address for purposes of hukou registration (the basis for one's ID card, health insurance, voting rights, and other forms of official license), as well as for electric and water services, mail delivery, etc. Taiwanese society contains a multitude of civic organizations used to manage collective affairs: community development associations, building management committees, surname and native-place associations, chambers of

commerce, etc. But the arrangements of registry sharing are made outside of such formal institutions. They extend along lines of intimate, particularistic or (in local idiom) ganqing/“sentiment”-based relations of kinship and friendship (cf. Fried 1953, Jacobs 1979).

My hukou registration was filed using the address of a friend's legal apartment several blocks away. At one point, an awkward spell in relations with this friend resulted in my official (as it were) channel of communication with the state being cut off for a while. During this period, I had the strange experience of running into a mutual acquaintance of my censusaddress friend, a woman I barely knew. Upon seeing me, she rummaged around in her purse and handed me a photograph of myself committing a traffic infraction, exhorting me to take care of this matter quickly, before the fines began to increase exponentially.

Traffic violations in Taiwan are often documented by hidden cameras, with the photograph and ticket being subsequently mailed to the census address at which the license plate is registered. Receiving a citation by purse is an outcome of the interface between the 
formal anchor of the registry address and informal networks of neighborly concern. Thus, as a law enforcement event, the experience was revelatory of Taiwan's "policing vernacular," i.e. the distinctive mode of police practice emergent from a local history of modern government (Hornberger 2011). The shared accountability of a registry address served to integrate an ethos of neighborliness and friendship into the formal enforcement of legal penalties. The result was a hybrid disciplinary regime that effectively fused intimate compassion with bureaucratic surveillance. Such arrangements are perfectly suited to maintaining the baroque complexity of order in cities built around and beyond the limits of law.

Taiwan's judicial architecture divides police into administrative and criminal branches, with emphasis on the former. ${ }^{1}$ The "front-line" of the police bureaucracy - its routine patrol and response capacity - is located in an administrative bureau called a paichusuo, a "dispatch post" or "substation." This is the neighborhood police station, and thousands of substations are scattered across the island. Historically speaking, paichusuo are the oldest element of modern Taiwanese policing. Many have been in continuous operation since the Japanese colonial government first built them in the late nineteenth century. Throughout this period, their operations have been defined by the population register; each paichusuo functions to keep one territorially defined unit of the state's records in order. ${ }^{2}$

I spent three years (2000-2003) doing ethnographic research in paichusuo in Taipei County. The substation where I spent most of my time was a three-story concrete building, the working facilities and residential barracks for 30 policemen. It was one of ten within its municipality, holding jurisdiction over a couple dozen city blocks with a population of about

\footnotetext{
${ }^{1}$ Taiwan's criminal justice system is inquisitorial, locating the agency of criminal prosecution in the Ministry of Justice rather than the Ministry of Interior (where the National Police Administration is located). There is a criminal detective division within the police force, but it is a specialized agency that does not maintain personnel in the neighborhood paichusuo.

${ }^{2}$ The Japanese population registry was substantially different from the Chinese, see Ts'ai 2009. However the administrative architecture at the substation-level was structurally similar.
} 
40,000. The census records for this population (still paper-based at that time) were held in the lockers of individual patrolmen. Each patrolman held the hukou records for their "beat," a territorially defined group of a few thousand people. Conversely, each registered inhabitant of the city had an individual patrolman as designated contact in the police bureaucracy. The patrolman and his census subjects were, in a sense, jointly responsible for any audit of their hukou records conducted by superordinate bureaus.

The substation was near a bridge. Under the bridge, across the street from the substation, sat one of the city's more spectacular embodiments of extralegal power: the headquarters of a taxi-driver's union. The union was huge and powerful, with dozens of chapters under centralized leadership. It controlled lucrative taxi stands outside the hotels and brothels of Taipei's red-light districts, and enjoyed a reputation for organized violence acquired during the political tumult of the early 1980s, when it served as a mobile strike force for the opposition movement prior to the end of martial law. The union headquarters was built of railroad-car-sized steel shipping containers, piled two-high for hundreds of meters along the river's levee to create a walled compound. At night, when bonfires backlit the chapter flags flying from the walls, it looked much like a medieval castle. Inside those walls, it was rumored, union chapters ran casinos, brothels and unlicensed petrol stations. But the substation police claimed ignorance. They never entered the compound unless explicitly invited (such as to the banquets hosted there during election season). One night on patrol, for example, I accompanied a patrolman answering a 119 call anonymously reporting illegal gambling inside the compound ("Now that's a patriotic citizen of the Republic of China ... and a sore loser!" the policeman laughed upon receiving the call). We leisurely walked across the street and chatted with a doorman for a considerable period of time before being invited inside and shown an empty room as evidence that nothing untoward was going on. 
It was a conventional move in the division of social control labor. Businesses hire doormen to liaise with patrolmen responding to calls at their establishment. Indeed, the doorman and the patrolman are, in a sense, structurally analogous figures within the larger arrangements of the city's overall political-economy. Both hold positions of subaltern authority under superiors tangled into the complexities of municipal politics. The escalation of disagreement in the street-level encounter between a patrolman and doorman invokes complicated networks of political patronage that both would rather leave undisturbed. From the policeman's perspective, this particular call was especially straightforward because of its location. Formally speaking, the land occupied by the union's compound was the site of a municipal renovation project scheduled for completion at an unspecified future date. The whole operation, in other words, rested on a property claim constituted by the political arrangements of (in local idiom) "closing one eye and opening the other." It was effectively "off the books" at the highest levels. Because the union compound was an unregistered space, there was no accountability in the police station for what went on there. For the routines of Taiwanese administrative policing, registration is a necessary step in making things policeable. That which is unregistered is unpoliceable. Political powers, like those of the taxidriver's union, use this to establish stable spaces of operation outside the policed order.

The situation is different when a registered hotel or private residence is used for gambling or prostitution. In that case, the policeman whose locker holds its registration is accountable for being the first to know and intervene. This arrangement underwrites a form of "brokered" administration ${ }^{3}$ with dynamics similar to those of my opening purse-bornecitation example, i.e. coordinated efforts to keep things from getting out of hand are integrated through a fusion of bureaucratic surveillance with intimate concern. An

\footnotetext{
3 " $[$ A]dministrative brokers facilitate the negotiation and the circumvention of the state, by its agents as well as by its users, attracting them on a common ground where the shared standards are different from those which are defined by the bureaucratic organizations" (Blundo 2006: 803).
} 
ethnographic picture of a paichusuo reveals a thriving community center, inhabited primarily by a class of people police refer to as "the locals" (difang renshi or, more wryly, "the local gentry," difang shenshi). As one patrolman glossed the category, "It's the vocational participants in local affairs ... people who are a bit more enthusiastic about participating in community affairs - the temple management committees, the village or borough chief, the village secretary, the popular representatives, the ones who are routinely active in the locality. ... There are even some with no formal status at all [who just] like to participate in 'backstage work' ... you know, the advisors and the vote brokers."

Administrative brokerage features prominently in the history of modern Chinese government. Prasenjit Duara's (1985) study of early Republican state formation, for example, found it characterized by "a variation of the state-making process wherein the formal structures of the state grow simultaneously with informal structures ... the formal state is dependent upon the informal structures to carry out many of its functions [yet] it is unable to extend its control over the latter" (Duara 1985: 132). And Phillip Huang (1993) has identified the formal-informal dynamics of this "Third Realm" as the main thread of continuity linking the modern Chinese administration of justice to its pre-modern precedents. Space limitations here preclude extensive ethnographic description of the brokering practices I observed in Taiwanese paichusuo, but I have elsewhere published accounts of the processes of negotiation through which police and "locals" cooperated to produce such records as traffic citations and accident reports (Martin forthcoming a), photographic evidence of a cleared hawker market (Martin 2007), and even the preliminary arrest report for a human trafficking case (Martin forthcoming b). In each case, an externally imposed demand for penal sanction temporarily destabilized the homeostatic equilibrium of networked accountability established within the architecture of local hukou registration. The real work of paichusuo policing, in 
other words, is maintaining the equilibrium of this local order, most especially against extrinsic demands for penal intervention.

This local order is defined by particularistic virtues. Police work, seen from ethnographic perspective, is discursive work (Manning 1977). In Taiwan, the discourse is structured by the terms through which people establish and uphold their local reputation. Participation in the local community is founded on particularistic bonds of ganqing "sentiment," spreading out into a web of guanxi (relationships), renqing (favors), mianzi (face), mingqi (fame), xinren (trust), guanxin (solicitude), limao (etiquette), yiqi (righteousness), de (virtue), ling (efficacy), and bao (reciprocity). This is a very specific, historically defined constellation of values. It is a system of ideas integrated by a structural logic into a robust cultural syndrome, a "particularistic" or "relational" cosmology of human association (Fei 1992). The local order kept by neighborhood police is defined by this cosmology, a civic ethos embodying the kind of moral character that motivates a friend of a friend to deliver a traffic citation.

\section{Policeable Virtues and the Role of Law.}

What does the ethnographic sketch presented above suggest for a broader understanding of policing, be it in terms of Asia or some sort of "Global South"? I will approach this issue here by juxtaposing two different theoretical frames. Each locates Taiwan's policing vernacular in a slightly different interpretive context. The contrast between them, then, suggests both the scope and the limits of Taiwan's significance for comparative policing studies. The first frame is Partha Chatterjee's (2004) postcolonial theory of democracy as the "politics of the governed." Certain aspects of Taiwanese policing resonate strongly with Chatterjee's description of India, suggesting that my ethnography does indeed speak to dynamics of wider significance. The limits of this generality, however, are revealed 
by the second moment of analysis where I juxtapose my findings against an account of policing in South Africa. Like Taiwan, South Africa is an "emergent democracy in which there is a plurality of policing providers" (Marks and Wood 2010: 311). Yet the South African response to the challenges of policing a post-authoritarian society involves a turn to law that diverges categorically from Taiwan's virtue-focused, registry-based system. The difference between South African and Taiwanese democratic policing suggests some of the difficulties involved in making generalizations about policing in post-authoritarian or postcolonial states, let alone any so-called "Global South."

Chatterjee's theory of post-colonial democracy focuses on the tension between governmentality and citizenship. In places - like India, Taiwan and South Africa - where colonization made people objects of policy long before decolonization opened the arena of citizenship, popular politics remains rooted in collective habits incubated within colonial arrangements of security and welfare governance. This establishes a form of "political society" which differs in various ways from the rights-focused bourgeois associational forms of "civil society." When decolonization finally opens democratic processes to the masses, the mode of democratic practice that unfolds from the established political society scandalize the civic sensibilities of the bourgeois elite, appearing as if "politics has been taken over by mobs and criminals" (Chatterjee 2004: 47). Such perceptions are well-documented in Taiwan (Chin 2003). And Chen Kuan-Hsing (2010) has used Chatterjee's theory to unpack the cultural content of Taiwan's contemporary "political society" in detail, finding the particularistic virtues of ganqing-based solidarity described above at its core.

Taiwan's registry-based policing system is exemplary of Chatterjee's depiction of colonial governmentality. The Japanese inaugurated it as an apparatus of counterinsurgency which securitized the social fabric through a system of collective responsibility for good behavior (Ts'ai 2009). Throughout the Japanese colonial and Chinese authoritarian period, it 
functioned as a mechanism of political surveillance designed to foreclose possibilities of organized resistance by imposing patterns of collective vulnerability and risk onto local communities. When democratic reform transferred control over police budgets and personnel decisions to local representative councils in the 1990s, the underlying administrative organization of policing through the territorially defined population registry did not change, even as the hukou's erstwhile function as a mechanism for centralized control was replaced by its new role as an arena for cultivating parochial democratic solidarities (Martin forthcoming b). In other words, democratic regime change preserved the established policeability of ganqing-based "traditional" virtues. They were hard-wired into in the locallevel patterns of mutual vulnerability and dependence that underwrite the discourse of moral standards which rationalizes the "natural" order of Taiwan's policed society (cf. Silver 1967).

The hukou remains the primary form of representation used by the Taiwanese state to account for its population. However, my ethnographic description above shows that the work of maintaining these records is embedded in a field of "tactical government" (Feldman 2008). The negotiated qualities of Taiwanese street policing use formal record-keeping as a resource for maintaining local networks of substantive trust. And this makes the aggregate picture of a-people-in-police created by the hukou system factually inaccurate. Taiwan's police registry, in other words, creates a sort of panoptical illusion possessing minimal qualities of "legibility" (Scott 1999). Taiwan's policing vernacular explicitly subordinates the utility of factual veracity to the values of traditional virtue. These virtues are embodied in the horizontal solidarities of trust and cooperation mobilized around collective projects of keeping the state's records in order. Taiwanese policing thereby serves to maintain a social order rationalized in terms of particularistic virtue.

To understand that this conspiratorial, duplicitous, extra-legal arrangement is not a pathology but rather a functional system of modern policing, consider Nils Christie's (2004) 
distinction between horizontal and vertical justice. For Christie, horizontal justice is justice negotiated among stakeholders; it is intimate, situational and community-based. Vertical justice, by contrast, is that imposed by external authority through formal legal institutions. Both kinds have their appropriate place. But for the routine adjudication of minor problems, Christie argues, the locally anchored, locally relevant, restorative qualities of horizontal justice are preferable. Taiwanese policing clearly embodies this order of priority. Indeed, the formal aspects of Taiwanese policing - the bureaucratic records which constitute the "vertical" dimension of state hierarchy (cf. Ferguson and Gupta 2002) - are used in practice as a site in which to cultivate community-based "definitions of the situation." The institution of the police registry constitutes a particular kind of juncture between the horizontal and vertical - or particularistic and general - dimensions in the administration of justice. Contemporary Taiwanese policing is, in other words, a mechanism for realizing the classically Confucian ideal of "governance through virtue"; the registry is a device for making, ganqing-based virtues policeable.

Policeable virtue provides an alternative to law as the foundation of police governance. It is a form of policing suited to Chatterjee's "political society." In Taiwan traditional virtue has become a policeable object, in the sense described by Gilberto Rosas' (2006) work on "policeability" in the borderlands. Non-citizens, holding no legal rights, are pure objects of governmentality. Yet wherever illegal immigration provides cheap docile labor, undocumented laborers are a core element of the socioeconomic status quo. "Undocumented migration is not a vector of social exclusion," wrote DeGenova (2002), "but rather is constituted to socially include people under conditions of enforced and protracted vulnerability" (DeGenova 2002: 429). It is a highly organized regime of subaltern inclusion. The mechanisms of its organization are the arrangements of documentary practice: who holds whose papers, who vouches, who guarantees, etc. The arrangements of registry sharing are, 
in Chatterjee's terms, a sphere of political society. And different arrangements entail specific social effects. The documentary practices of police status weave a social fabric of vulnerability and risk that renders particular social objects susceptible to fine-grained management through the application of police force i.e. "policeable." In Rosas' work on the Mexican-American borderlands, policeable objects are things like ethnicity, gender, class and family status. Taiwanese policeability, by contrast, has replaced the crude "unintended" dynamics of undocumented migration with the historical wisdom of a political tradition in which sovereignty was originally conceived in terms of cultural inscription (Fei 1992). From its inception, the police registry has been consciously designed to function as a mechanism of inscription that improves the quality of the population by rendering civic virtue into a policeable object.

This is a culturally and historically particular dynamic. Consider, in this respect, the contrast between Taiwan and South Africa for what it reveals about the imagined place of law within the organization of police. Chatterjee's approach to civil society, as a distinctively bourgeois institution, emphasizes a central insight of critical legal studies: it is an ideological move to conflate the "natural order" of a community with the content of its criminal law (Balbus 1977). In Taiwan, the institutionalized policeability of virtue allows law to remain a marginal element in the imagination of social order (Winn 1994). Not so in South Africa. To be sure, Marks \& Wood describe South Africa's policing predicament in terms similar to Taiwan, a "nodal and fluid policing landscape" deploying a brokered system of social control to diffuse policing practices across a range of actors (Marks and Wood 2010: 312). Unlike Taiwan, however, South African social control is violent and unstable, raising urgent normative questions of "Who the police should be?" Marks and Wood's proposed answer seeks to "[draw] a clear and robust blue line that distinguishes between the authority and capabilities of the public police and that of other policing actors" (Marks and Wood 2010: 
320). And, for reasons elaborated at length in their article, law is center of this line; as they put it (quoting Reiner) "police intervention should be confined to cases where there is clear evidence of law-breaking, and should take the form of the invocation of legal powers and criminal process" (Marks and Wood 2012: 321). In Taiwan, by contrast, the invocation of legal powers and criminal process marks the collapse of the particularistic trust that holds together the peaceful and prosperous - if extra-legal - arrangements of local policed order. The historically derived, culturally structured arrangements of Taiwanese modernity endow it with a policing capacity that is clearly different from other places with other histories and cultures.

\section{Conclusion}

Michel-Rolph Trouillot (2001) suggested we best understand the state through attention to its ethnographically apparent effects, such as the way it produces individualized subjects in a field of collective subjectivity. Taiwan's hukou-based policing system produces subjects and solidarities in reference to a policeable set of traditional virtues. This exemplifies the distinctively Asian "historical ontology" Chen Kuan-Hsing (2010) found at the basis of the contemporary Taiwanese state. Like Chen, my analysis has revealed the institutional forms of so-called "Western" modernity to be "fragments internal to the local," focusing on historical process of hybridization that produce a modernity that is "not what we imagined at the initial moment of translation at all, but a localized product of the blending process. It is something new" (Chen 2010: 244). The tropes of civil virtue that have taken shape as the organizing principles of Taiwanese policing are recognizably traditional, but at the same time they have become "something new." They have become policeable objects of modern administration: inscribed in the documentary practices of population registration, embedded in a naturalized division of social control labor, and institutionalized as collective 
habits of response to trouble. Seen in the light of anthropological analysis, Taiwanese policing reveals how a culturally ordered gestalt can be preserved as foundation for an authentically vernacular practice of modern government. What this means for larger concerns about "Asian," "post-colonial," or "post-authoritarian" policing will eventually become clear through comparative work like that organized through this issue of Theoretical Criminology.

\section{Bibliography.}

Anderson, Benedict (1991) Imagined Communities. London: Verso

Balbus, Isaac (1977) Commodity form and legal form: An essay on the 'relative autonomy' of the law. Law \&. Society Review 11 (3): 571-88.

Blundo, Giorgio (2006) Dealing with the local state. Development \& Change 37 (4): 799 819.

Chen, Kuan-Hsing (2010) Asia as Method. Durham: Duke

Christie, Nils (2004) A Suitable Amount of Crime. NY: Routledge

DeGenova, Nicholas. (2002) Migrant 'illegality' and deportability in everyday life. Annual Review of Anthropology (31): 419-447

Duara, Prasenjit (1985). Culture, Power and the State. Stanford: Stanford.

Fei Xiaotong (1992) From the Soil. Berkeley: University of California Press

Feldman, Ilana (2008) Governing Gaza. Durham: Duke

Ferguson, James and Akhil Gupta (2002) Spatializing states. American Ethnologist 29 (4): 981-1002

Fried, Morton (1953) The Fabric of Chinese Society. NY: Praeger

Hornberger, Julia (2011) Policing and Human Rights. NY: Routledge

Huang, Philip C. C. (1993) Public sphere/civil society in China? Modern China 19 (2): 216- 
Jacobs, J. Bruce (1979) A preliminary model of particularistic ties in Chinese political alliances. The China Quarterly (78):237-273.

Lo, Ming-Cheng and Eileen Otis (2003) Guanxi civility. Politics \& Society 31 (1): 131-162

Martin, Jeffrey T (2007) A reasonable balance of law and sentiment. Law and Society Review 41 (3): 665-697

Martin, Jeffrey $\mathrm{T}$ (forthcoming a) Police as Linking Principle/s. In William Garriott (ed) Police in Practice. NY: Palgrave

Martin, Jeffrey T. (forthcoming b) Legitimate Force in a Particularistic Democracy. Law \& Social Inquiry

Rosas, Gilberto (2006) The managed violences of the borderlands. Latino Studies 4 (4): 401 418.

Scott, James C (1998) Seeing Like a State. New Haven: Yale

Senger, Harro von (2009) Looking outwards. In L'Etat Civil Du XXIeme Siecle: Declin ou Renaissance, Strasbourg, France. 13-14 March, 2009.

Silver, Allan (1967) The demand for order in civil society. In David Bordua (ed) The Police: Six Sociological Essays. NY: John Wiley and Sons

Trouillot, Michel-Rolph (2001) The anthropology of the state in the age of globalization. Current Anthropology 42 (1): 125-138

Ts'ai, Caroline (2009) Taiwan in Japan's empire building. NY: Routledge. 